\title{
Mining Reclamation Activities in the Perspective of Mining Law in Indonesia
}

\author{
Dr. H. Joni, SH.MH. \\ Lecturer at STIH Habaring Hurung Sampit, Kotawaringin Timur, \\ Central Kalimantan. Notary, Legal and Social Research
}

\begin{abstract}
The passing of Law No. 3 of 2020 concerning Minerals and Coal (Minerba), has given a new color to mineral and coal mining in Indonesia. With regard to reclamation problems, especially those that occur in areas that do not proceed as regulated, companies only want to take advantage without having to think about their responsibilities for reclamation, especially in the "under" mine. When seen, there is a lot of underneath from the day it grows. It is hoped that the regulations that are passed regarding Minerba can be fully implemented so that mining actors are deterred and responsible for carrying out reclamation. Of course, this is not free from cooperation between parties and there is no practice of bribery so that the law cannot be bought by money. Although basically everyone needs money to meet their needs and their families. When compared with the old and new Minerba Law, the old Law can use a third party to reclaim the guarantee fund. Thus the reclamation can still run. However, the new Minerba Law added with criminal penalties for companies or mining actors who do not want to reclaim, did not bring. For this reason, reclamation activities should be carried out and at the same time monitoring that is consistently enforced in the activity concerned. Supervision is needed as part of law enforcement, which includes the reclamation process and when untruth is found in reclamation activities, and immediate action should be taken to correct it in accordance with the prevailing laws and regulations.
\end{abstract}

Keywords: Reclamation, Law Enforcement, Mining Law

DOI: $10.7176 / \mathrm{JLPG} / 106-07$

Publication date: February $28^{\text {th }} 2021$

\section{A. Background}

The teaching of morality which contains social values, is based on the old literary language about the relationship between law and mining, which is the basis for the elaboration of reclamation problems. The teachings referred to as listed in the old literary book by Pujangga Sastraprateja. The stanza of the sentence is written: The holder of the sovereignty forms the law, his heart must be pure and clear, the mind must be straight, not twisted, knowledgeable, then pray a lot. If his heart is dirty and stained, angkara will enter, and become a work covered with calamity. Like forging a keris, forging the chapters in the law book, the master must be clean, clear, surrender to the Creator, immaculate in his mind and soul, and his prayer slings through the sky. If it is stained, it is ridden by wickedness, it will be difficult for the people, it will be difficult for the nature, it will be difficult for the children and grandchildren, then the country will be destroyed. That is the legal morality of the Sovereign. ${ }^{1}$

From the perspective of mineral and coal management, it is known that on June 10, 2020, Law Number 3 of 2020 concerning Amendments to Law Number 4 of 2009 concerning Mineral and Coal Mining was passed. Before the law was passed by the DPR and signed by the President, experts opposed several articles which were felt to be more favorable to foreigners than to the people. However, related to reclamation, the new Minerba Law has a more deterrent effect on IUP and IUPK holders who do not carry out reclamation and post-mining activities, and even criminal sanctions for those who do not implement it.

Reclamation activities are activities carried out throughout the stages of the mining business to organize, restore and improve the quality of the environment and ecosystem so that it can function again according to its purpose. ${ }^{2}$ This needs to be regulated because in mining activities it can be said that almost all of them cause environmental damage. Therefore it is necessary to give the obligation to the company to restore the environment in the implementation of mining activities that have been damaged. ${ }^{3}$

One of the toughest challenges facing countries rich in mineral resources is the rise of illegal mining. The problem is that mining is not only detrimental to the state financially, but often causes various problems such as environmental damage, social conflicts, economic inequality or even new poverty. ${ }^{4}$

That the most severe impact of mining activities is on the environment and social life. Many watersheds

\footnotetext{
${ }^{1}$ https://anal.kontan.co.id/news/menguji-konstitusionalitas-uu-minerba, Testing the constitutionality of the Minerba Law by Ahmad Redi Head of the Tarumanegara University Law Studies Program. Retrieved 22 October 2020.

${ }^{2}$ Murtadho. 2018. Human nature in their interaction with nature. Yogjakarta: UIN Sunan Kalijaga Press. Page. 35.

${ }^{3}$ Republic of Indonesia, Law Number 3 of 2020 concerning Mineral and Coal Mining. Article 1 number 26.

${ }^{4} \mathrm{http}: / /$ www.iesr.or.id/2017/10, Discussion of Illegal Mining in Indonesia and its Challenges towards ASEAN. Jakarta: Institute for Essential Service Reform.
} 
have been damaged by excavation activities or have been polluted by the use of chemicals such as stealing and cyanide. Excavation Community mining also causes a decrease in the carrying capacity of the environment because they are only able to process up to $60 \%$ of mining products, the rest which is still in the form of chunks of land is finally dumped into the surrounding environment. ${ }^{1}$

This phenomenon deserves great attention from the government in seeking a sustainable and environmentally friendly mining management system. The government needs to prepare a mining management concept that can be applied both at the national and regional levels, increasing mining goods is a non-renewable natural resource. ${ }^{2}$

For this reason, more disciplined and consistent regulations are needed so that they are able to control excessive mining activities and cause environmental damage, one of which is to pay special attention to regulations regarding reclamation. Thus the point is to improve or organize the use of disturbed land as a result of mining business activities, so that it can function and be efficient according to its allotment. Environmentally sound development is an important necessity for every nation and country that desires the preservation of natural resources. Therefore, natural resources need to be preserved and maintained for the continuation of human life today, as well as for future generations. ${ }^{3}$

Activities such as forest clearing, mining, clearing agricultural land and settlements are responsible for the damage to the ecosystem that occurs. The consequences include poor physical, chemical and biological conditions of the soil, such as a non-profiled soil layer, bulk density (compaction), deficiency of important nutrients, low $\mathrm{pH}$, pollution by heavy metals on ex-mining areas, and decrease in soil microbial population. For this reason, an activity is needed as an effort to preserve the environment so that further damage does not occur. These efforts can be pursued by rehabilitating damaged ecosystems. ${ }^{4}$

With this rehabilitation, it is hoped that it will be able to repair the damaged ecosystem so that it can recover, be closer to or even better than its original condition (Rahmawaty, 2002). Mining activities of valuable minerals from the layers of the earth have been going on for a long time. Over a period of 50 years, the basic concept of processing has remained relatively unchanged, what has changed is the scale of its activities. The mechanization of mining equipment has made the mining scale bigger and bigger. The development of processing technology has made the extraction of low grade ore more economical, so that it is getting wider and deeper to reach the earth's layer far below the surface. This causes mining activities to have significant environmental impacts very large and important. The impact of mining activities has a very significant impact, especially in the form of contamination of surface water and ground water. Natural resources that cannot be renewed such as oil and other mining materials, when extracted, must be in careful planning to realize a sustainable national development process. ${ }^{5}$

Mining activities are complex and very complex business activities, full of risks, are long-term business activities, involve high technology, are capital intensive, and have regulations issued from several sectors. In addition, mining activities have great environmental changeability, so that it requires careful total planning from the initial stage to the post-mining stage. When opening a mine, you must understand how to close a mine. Mine rehabilitation / reclamation is progressive in nature, according to the post-mining land use plan. ${ }^{6}$

The stages of mining planning activities include resource and reserve assessment, final / ultimate pit limit design, mining phasing, mine production scheduling, waste dump design, calculation of equipment and labor requirements, calculation of capital costs and operating costs. , financial evaluation, environmental impact analysis, corporate social responsibility (Corporate Social Responsibility) including community development (Community Development) and mine closure. Mine planning, since the beginning, has made systematic efforts to anticipate environmental protection and the development of employees and communities around the mine. ${ }^{7}$

The problem revolves around how reclamation is carried out after mining in Indonesia, based on Law no. 3 of 2020 concerning Minerals and Coal.

\section{B. Regulations in the Mining Sector Related to Reclamation.}

Before Law Number 3 of 2020 was passed, several experts challenged it, because there were various potential morality defects seen in the formation of this Minerba Law, both procedural and substance morality. The first defect of procedural morality is that the Minerba Bill does not meet the carry over criteria in accordance with Article 71A of Law No. 15 of 2019 concerning Amendments to Law No. 12 of 2011 concerning the

\footnotetext{
${ }^{1}$ Ibid. Page. 45

${ }^{2}$ Tri Hayati, a New Era of Mining Law Under the Regime of Law no. 4 of 2009. Jakarta: Yayasan Pustaka Obar Indonesia (2018). Page 256.

${ }^{3}$ Ibid. Page 33

${ }^{4}$ Suwandhi. 2017. Geological Aspects in the World Mining Map. Bandung: Bhioporus. Page 14

${ }^{5}$ Ibid. Page 21

${ }^{6}$ Tri Hayati. Op. Cit. Page 56

${ }^{7}$ Ibid. Page 60
} 
Establishment of Legislation. ${ }^{1}$

In Article 71A of Law no. 15 of 2019 stipulates that in the event that the discussion of the Bill has entered into the discussion of the Inventory of Problems (DIM) during the current DPR membership period, the results of the discussion of the Bill will be submitted to the DPR for the next period and based on the agreement of the DPR, President, and / or DPD, the Bill entered back into the list of the mid-term National Legislation Program (Prolegnas) and / or annual priority Prolegnas.

That the Minerba Bill is a bill initiated by the DPR which has been drafted since the 2014-2019 DPR period and until the DPR's term of office ended in September 2019 there has not been any discussion of the DIM of the Minerba Bill. Based on Article 71A of Law Number 15 of 2019 that the carry-over discussion of the bill must meet the requirements that the previous period DPR had discussed DIM, even though the previous period DPR had not yet discussed DIM on the Minerba Bill. This means that the carry over of the Minerba Bill to the DPR for the 2019-2024 period is clearly illegal because it contradicts Article 71A of Law No. 15 of 2019. ${ }^{2}$

Second, the absence of the role of the DPD RI in accordance with Article 22D of the 1945 Constitution and the Decision of the Constitutional Court (MK) No.92 / PUU-X / 2012. The discussion of the Minerba Bill must involve the Regional Representative Council (DPD). This is based on Article 22D of the 1945 Constitution of the Republic of Indonesia, Article 249 of Law Number 17 of 2014 concerning the MPR, DPR, DPD and DPRD (MD3), as well as the Constitutional Court Decision No. 92 / PUU-X / 2012. In the Constitutional Court Decision No. 92 / PUU-X / 2012 states that DIM is proposed by the President and DPD if the bill comes from the DPR. In fact, no DIM was made by the DPD during the discussion of the Minerba Bill. The absence of DIM from the DPD and the absence of the DPD's involvement in the preparation and discussion of these clearly contradicts the mandate of Article 22D of the 1945 Constitution, Law no. 12 of 2012, and the Constitutional Court Decision. ${ }^{3}$

Third, the Minerba Bill does not fulfill the principle of transparency in the formation of laws and regulations as stipulated in Article 5 of Law Number 12 of 2011. The discussion of the Minerba Bill does not involve public participation and stakeholders at large, including local governments and BUMN. This clearly violates the principle of transparency, that in the formation of laws and regulations it is transparent and open. Thus, all levels of society have the widest opportunity possible to provide input in the formation of laws and regulations.

Furthermore, there is a moral flaw related to the substance of the Minerba Bill which ignores the SDA ideology as stated in Article 33 of the 1945 Constitution of the Republic of Indonesia. Article 169A of the Minerba Law regulates the provisions for the extension of companies holding work contracts (KK) and coal concession work agreements (PKP2B) with Special Mining Business Permits. (IUPK) without giving priority to BUMN and BUMD to cultivate it. The impartiality of the government and the DPR in the Minerba Law is a form of state oppression against state-owned companies themselves, unless the state controllers have been flagged because of a conflict of interest with their businesses or groups.

Article 33 paragraph (2) and paragraph (3) of the 1945 Constitution of the Republic of Indonesia clearly mandates state control over natural resources, one of which is through management (behersdaad). In various decisions, the Constitutional Court stated that the first level of state control over natural resources is through direct management of natural resources by the state through state companies (BUMN).

In fact, this state-owned company was not prioritized at all in the IUPK over PKP2B which ended its production operation. Not to mention the question of eliminating the authority of local governments in the implementation of mineral and coal, even though Article 18A of the 1945 Constitution states that the relationship between the use of natural resources from the central government and regional governments is regulated and implemented fairly and in harmony based on law.

Finally, the constitutionality of the Minerba Law will certainly be tested by community groups to the Constitutional Court so that the articles in the Minerba Law are returned to the will of Pancasila and the 1945 NRI Constitution. Minerba must be controlled by the state for the greatest welfare of the people. ${ }^{4}$

In the mineral and coal mining sector, there are also regulations related to environmental restructuring and restoration. Mineral and coal mining is managed on the basis of: ${ }^{5}$

a. Benefits, equity and balance;

b. Siding with the interests of the nation;

c. Participation, transparency and accountability;

\footnotetext{
${ }^{1}$ Hasbi Ali. 2010. New Paradigm of Mineral and Coal Management. Maxsar: Indonesian Muslim University. Page 12.

${ }^{2}$ Ibid. Page 16.

${ }^{3}$ Muhadar Rajikum. 2017. Decision of the Constitutional Court on Dispute Authority of State Institutions. Jakarta: Phobia. Page 34.

${ }^{4}$ https://anal.kontan.co.id/news/menguji-konstitusionalitas-uu-minerba, Testing the constitutionality of the Minerba Law by Ahmad Redi Head of the Tarumanegara University Law Studies Program. Retrieved 22 July 2020.

${ }^{5}$ Republic of Indonesia, Law Number 4 of 2009 concerning Mineral and Coal Mining. Article 18.
} 
d. Sustainable and environmentally friendly; ${ }^{1}$

However, in the new Law no. 3 of 2020 is amended by sound, Article 18 paragraph (1) The determination of the area and boundaries of Metal Mineral Mining Business License Area and Coal Mining Business License Area as referred to in Article 17 must consider:

a. National Mineral and Coal management plan;

b. Availability of data on Mineral or Coal resources and / or reserves; and

c. Region status. ${ }^{2}$

Paragraph (2) Data on Mineral or Coal resources and / or reserves as referred to in paragraph (1) letter b comes from:

a. Results of Investigation and Research activities conducted by the Minister;

b. The results of the evaluation of the Metal Mineral Mining Business License Area or Coal Mining

Business License Area which are returned or reduced by the IUP holder; and / or

c. Evaluation results of metal mineral or coal WIUP whose IUP has expired or been revoked.

When compared to Article 18 in the old and new mineral and coal laws, the new law has a flexible nature in view of the conditions in the field and is more likely to be conditioned.

by elements moving in it. Especially it is very easy to find opportunities for profit on those who have more power and finance, compared to the benefits of the people and the environment based on natural resources.

This is also stated in article 39 of Law no. 4 of 2009 that at the IUP Exploration stage mining companies are required to fulfill, among others, the AMDAL. At the IUP Production Operation stage is required to fulfill, among other things, the Environment including Reclamation and Post-mining as well as a guarantee of Reclamation and Post-mining Funds.

However, Law No.3 of 2020 was amended so that it reads as follows:

Article 39: "IUP as referred to in Article 36 paragraph (1) contains at least:

a. Company profile;

b. Location and area;

c. Type of commodity cultivated;

d. Obligation to place a guarantee of seriousness of Exploration;

e. Working capital;

f. The validity period of the IUP;

g. IUP extension;

h. Obligation to settle land rights;

i. Obligation to pay state revenue and regional income, including obligation of fixed fee and production

fee;

j. Obligation to carry out Reclamation and Post-mining;

k. Obligation to prepare environmental documents; and

1. Obligation to carry out Development and Empowerment of communities around WIUP. ${ }^{3}$

The reclamation and post-mining guarantees that are not included in the new mineral and coal law really raise a big question about the sustainability of natural resources for the next life. Environmental obligations in carrying out mining activities are more specifically regulated in Government Regulation No. 78/2010 concerning "Reclamation and Post-Mining". Environmental obligations mandated by PP No. 78/2010. Implementation of reclamation by holders of Exploration IUP and Exploration IUPK must comply with the principles:

a. Protection and management of the mining environment;

b. Occupational Health and Safety;

The implementation of reclamation by the Holder of Production Operation IUP and Production Operation IUPK must fulfill the following principles:

a. Protection and management of life;

b. Occupational Health and Safety;

c. Mineral and coal conservation; ${ }^{4}$

The principles of protection and management of the mining environment as referred to above, at least fulfill:

a. Protection of the quality of surface water, ground water, sea water, ground dam and air based on quality standards or environmental damage standard criteria in accordance with statutory regulations;

b. Protection and restoration of biodiversity;

c. Guarantee of the stability and safety of overburden, tailings ponds, ex-mining areas and other rock structures;

\footnotetext{
${ }^{1}$ Hasbi Ali. Op. Cit. Page 33

${ }^{2}$ Ibid. Page 36

${ }^{3}$ Yayat Sukiyat. 2019. The Relationship between Mineral and Coal Management and Environmental Sustainability. Bandung: Lapperea. Page 21.

${ }^{4}$ Ibid. Page 23.
} 
d. Use of ex-mining land according to its allotment;

e. Pay attention to local social and cultural values;

f. Protection of water quantity according to statutory regulations. ${ }^{1}$

The principles of occupational safety and health include (a) safety protection for every worker / laborer, and (b) protection of every worker / laborer from occupational diseases. Furthermore, the principles of mineral and coal conservation include;

a. Optimal mining;

b. Use of effective and efficient processing and refining methods and technologies;

c. Management and or utilization of marginal reserves, low grade minerals, and associated minerals as well as low quality coal;

d. Structuring unmined mineral and coal resources and reserves as well as residual processing and refining; ${ }^{2}$

In the event that the associated minerals from the remaining mining, processing and refining contain radioactivity, it is obligatory to carry out a radiation safety analysis for the tenorms and to carry out interventions on radiation exposure originating from the tenorm in accordance with the statutory regulations.

According to Government Regulation Number 78 of 2010 concerning reclamation and post-mining articles 5 and 6, it reads as follows:

Reclamation and Postmining Administration, as follows;

a. The holder of an Exploration IUP and an Exploration IUPK, before carrying out exploration activities, is obliged to prepare a reclamation plan based on environmental documents in accordance with the provisions of laws and regulations in the field of environmental protection and management.

b. The reclamation plan is contained in the exploration work plan and budget;

c. Holders of IUP exploration and IUPK exploration who have completed feasibility study activities must submit an application for approval of reclamation plans and post-mining plans to the minister, governors or regents / mayors according to their respective authorities;

d. Reclamation plans and post-mining plans are submitted together with applications for Production Operation IUP and Production Operation IUPK;

e. Reclamation and post-mining plans are prepared based on environmental documents that have been approved by the competent authority;

f. The reclamation plan and post-mining plan must be in accordance with; ${ }^{3}$

1) The principle of protection and management of the environment as well as safety and health of mining work;

2) Mining systems and methods based on a feasibility study;

3) The specific conditions of the mining business permit area; and

4) The provisions of laws and regulations. ${ }^{4}$

The reclamation plan is compiled for a period of 5 (five) years and it contains the plan for each year. The reclamation plan contains at least;

a. Land use before and after mining;

b. Land clearing plan;

c. Reclamation program for disturbed land;

d. Success criteria include the standard of success in land arrangement, revegetation, civil works and final completion;

e. The reclamation cost plan consists of direct costs and indirect costs. ${ }^{5}$

Holders of IUP and IUPK, both at the exploration stage and at the production operation stage are obliged to provide reclamation and post-mining guarantees, as mandated by Article 29 of Government Regulation Number 78 of 2010 concerning reclamation and post-mining. The reclamation guarantee is placed with a state bank in the form of a time deposit within a maximum period of 30 days after the work plan and budget for the exploration phase are approved. The recalmation guarantee for the opera production stage can be:

(a) Joint account at a government bank,

(b) Time deposits at government banks.

(c) Bank guarantee at a government bank or national private bank, or

(d) Reserve accounting 6

Placement of reclamation guarantees does not eliminate the obligation of IUP and IUPK holders to carry

\footnotetext{
${ }^{1}$ Ibid. Page 30

${ }^{2}$ Hasbi Ali. Op. Cit. Page 46.

${ }^{3}$ Loc. Cit.

${ }^{4}$ Ibid. Page 22.

Iskandar Zulkarnain. 2019. Mining Without Permits, Problems Management of Traditional Mining Materials. Yogyakarta: Aswaja. Page 37.

${ }^{5}$ Ibid. Page 24.

${ }^{6}$ Endang Sukarmini. 2019. Responsibility for Mineral and Coal Management according to Law. Yogjakarta: Aswaja. Page 34.
} 
out reclamation.

According to Iskandar Zulkarnain, one of the factors causing the occurrence of illegal mining is the existence of Government Regulation No. 23/2010 which is difficult to apply in the field. The government treats community mining equally with companies, where the community must also apply for mining permits and are also given the obligation to carry out reclamation, even though with the Regional Government. This causes mining activities carried out by the community often without a permit. They also don't care about environmental or work safety aspects, let alone improving the post-mining environment.

Mining also does not guarantee that it can boost economic growth for the communities around the mine, because most of the owners of capital and workers come from outside the region. ${ }^{1}$

The existence of illegal mining has worsened the picture of mining activities in Indonesia. This also has an impact on the companies responsible for being affected by being accused of causing environmental damage. As a further consequence, the feelings of the responsible companies are treated the same, which of course creates injustice. However, on the other hand, according to the Chairman of the Energy and Mineral Resources Sector, APKASI, it is still necessary to observe that there are still many mining entrepreneurs who do not carry out postmining reclamation activities correctly and precisely or have not even done it at all, so that pollution and environmental damage still occur in the area. ${ }^{2}$

Meanwhile, the regional government as the supervisor has not fully understood the importance of postmining land reclamation activities or has not optimally carried out its supervision. Even this ineffective supervision can be caused by the minimum number of mine supervisors, especially in the regions. So it is necessary to have additional mining supervisors in the regions so that the supervision can be increased and effective. In addition, the supervision carried out by the Central Government to Regional Governments has also been biased since the era of the regional administration ethonomy. Central supervision seems to have become disconnected and its existence in the regional government has disappeared (with the elimination of regional offices in district and city governments as an implementation of deconcentration).

Returning to the philosophy of natural resource management, according to the mandate of Article 33 paragraph (3) of the 1945 Constitution, mining activities are aimed at the welfare of the community, both present and future. For this reason, mining operations need to be optimized by means of mechanization of excavation and processing activities so that they can be extracted and processed economically. One of the main factors in creating optimization of mining exploitation, it is necessary to make good planning and implement proper and correct mining techniques. ${ }^{3}$

Mining activities that comply with good and correct mining principles, among others, must pay attention to the following:

a. Physical and chemical environment;

b. The social and economic environment of the surrounding community;

c. Post mining environment. ${ }^{4}$

Good and correct mining management needs to be continuously studied and developed in today's mining business activities. Through the application of good mining practices it can be avoided waste of natural resources, achieving optimization of natural resources, protecting environmental functions and protecting occupational safety and health. Based on Article 95 of Law Number 4 of 2009 which was amended into Article 96 of law number 3 of 2020 which reads: "in the application of good mining engineering principles, IUP or IUPK holders are required to implement:

1. Mining safety provisions;

2. Mining environmental management and monitoring, including Reclamation and Post-mining activities;

3. Mineral and Coal conservation efforts; and

4. Management of mine residue from a development business activity in solid, liquid, or gas form until it meets environmental quality standards before being released into environmental media. ${ }^{5}$

Regulations to carry out proper and correct mining to prevent the emergence of massive environmental damage have been made and it is up to the enforcement of these regulations. This is also a quite complicated problem in its implementation, resulting in various deviations from existing regulations or abuse of authority of the licensing officials at the local government level. ${ }^{6}$

\footnotetext{
${ }^{1}$ Se: APKASI stands for the Association of Indonesian District Governments. in Iskandar. Op. Cit. Page 56.

${ }^{2}$ Suyartono, 2017. Good Mining Practice, 2nd edition. Semarang: Petraya Offset Publisher. Page 7.

${ }^{3}$ Ibid. Page 9.

${ }^{4}$ Ibid. Page. $80-82$

${ }^{5}$ Jumikun Toemon. 2009. Mining Environmental Law, a Natural Resource Management Orientation. Papers at a Seminar on Energy Resources. IPB Bogor, 29-30 July 2009. Page. 3

${ }^{6}$ Ibid. page 32
} 


\section{Fundamental Changes to Mining Sector Regulation in Law no. 3 of 2020}

It is necessary to understand that technically, the definition of mining engineering is an art or engineering and science that is applied to the mining process and mining operations. Minerals are inorganic and homogeneous solid objects that occur naturally, have certain physical and chemical properties, can be single elements $(\mathrm{Au}, \mathrm{Cu}$, $\mathrm{Ag})$ or compounds $(\mathrm{NaCl}, \mathrm{CaCO} 3)$. Coal Sedimentation of carbonic organic compounds that are formed naturally from plant remains.

Mining activity stages (based on Law No.4 of 2009):

1. General Investigation, mining activity stage to determine regional geological conditions and indications of mineralization. Exploration, the mining activity stage to obtain information about the location, shape, dimensions, distribution, quality and measurable resources of minerals, as well as information on the social and environmental environment.

2. Feasibility Study, the stage of mining business activities to obtain detailed information on all related aspects to determine the economic and technical feasibility of the business. ${ }^{1}$ mining, including environmental impact analysis and post-mining lanning.

3. Production Operation, the mining activity stage which includes construction, mining, processing, refining, including transportation and sales as well as means of controlling environmental impacts in accordance with the results of a feasibility study.

4. Construction, mining business activities to carry out mining construction of all production operation facilities, including environmental impact control.

5. Mining, part of the mining business activity to produce minerals or coal and associated minerals.

6. Processing and Purification, mining business activities to improve the quality of minerals and coal and to utilize and obtain associated minerals.

7. Transportation, mining business activities to move minerals and / or coal from the mining area and / or processing and refining places to the place of delivery.

8. Sales, mining business activities to sell mineral or coal mining products.

9. Reclamation, activities carried out during the mining business stages to organize, restore and improve the quality of the environment and ecosystem so that it can function again according to its designation.

10. Post-mining activities, activities that are planned, systematic and sustainable after the end of part or all of the mining business activities to restore the functions of the natural environment and social functions according to local conditions throughout the mining area. ${ }^{2}$

In relation to material substance, according to the types produced in Indonesia there are, among others, oil and natural gas mining; mineral metals such as tin, gold, nickel, copper, manganese, mercury, iron, sulfur, etc. and organic materials such as coal, precious stones such as diamonds, and others.

Seeing the very wide scope of mining mining development, starting from mapping, exploration, exploitation of energy and mineral sources as well as research on mineral deposits, processing of mining products and possibly to the use of mining materials that cause environmental disturbances, it is necessary to pay attention and control to the danger of environmental pollution and changes in the balance of the ecosystem, so that this sector which is vital for mining development can be maintained. ${ }^{3}$

\section{Existence of Reclamation Arrangements in Mineral and Coal Management Based on Law No.3 of 2020} Law Number 3 of 2020 concerning Amendments to Law Number 4 of 2009 concerning Mineral and Coal Mining or the Minerba Law was enacted on June 10, 2020. In the new Minerba Law, there are a number of points that have changed, one of which is related to reclamation and post mining activities. As is well known, in accordance with good and correct mining principles, every company that has a Mining Business Permit (IUP) and a Special Mining Business Permit (IUPK) must make an environmental management plan that is related to reclamation and post-mining.

Referring to the old Minerba Law, namely Article 100 of Law no. 4 of 2009, it is said that holders of Mining Business Permits (IUP) and Special Mining Business Permits (IUPK) are required to provide reclamation guarantee funds and post-mining guarantees. If the IUP and IUPK holders do not carry out the reclamation according to the approved plan, the minister, governor or regent / mayor in accordance with their authority can assign a third party to carry out reclamation and post-mining with the guarantee fund. ${ }^{4}$

The obligation to undertake safeguards in such a way as mining equipment / infrastructure, including land ex-mining areas and land around the former mining area so that it does not pose a danger to the surrounding community, can be done, either through implementing mining closure in accordance with mining closure procedures stipulated by the Government, or through mining closure procedures. implementation of reclamation

\footnotetext{
${ }^{1}$ Ibid. Page 37

${ }^{2}$ Ibid. Page 45

${ }^{3}$ Sukadarrumidi, 1999, Bahan Galian Industri, Yogyakarta: Gadjah Mada University Press Page 22

${ }^{4}$ Salim, 2015. Hukum Pertambangan Di Indonesia, Jakarta : Rajawali Pers. Page 34.
} 
of ex-mining areas. Provisions regarding reclamation are regulated in the Minister of Energy and Mineral Resources Regulation Number 18 of 2008 concerning Mine Reclamation and Closure.

Reclamation is an activity that aims to improve or organize the use of disturbed land as a result of mining business activities so that it can function and be effective according to its purpose. Some things that must be considered in connection with the implementation of reclamation are as follows:

Reclamation must be carried out no later than 1 (one) month after there is no mining business activity on the disturbed land, which includes:

a. Ex-mining land; and

b. Land outside ex-mining, which includes:

(1) landfill cover;

(2) stockpile of raw / production materials;

(3) transportation routes;

(4) processing / refining plant / installation;

(5) offices and housing;

(6) port / jetty. ${ }^{1}$

The implementation of the reclamation is reported annually by the mining company to the Minister, Governor or Regent / Mayor, according to their authority. In the event that the Minister, Governor or Regent / Mayor deems that the company does not meet the success criteria for the implementation of reclamation, either based on evaluation of reports and / or based on field assessments, the Minister, Governor, or Regent / Mayor according to their respective authority may appoint a third party to carry out reclamation activities with using the Reclamation Guarantee, as further described below. ${ }^{2}$

Reclamation is carried out by mining companies according to Law no. 3 of 2020 must be in accordance with the Reclamation Plan, including changes to the Reclamation Plan, which has been approved by the Minister, Governor or Regent / Mayor, in accordance with their respective authorities. The Reclamation Plan is prepared for implementation every 5 (five) years with annual details including land use before and after mining, land clearing plans, reclamation programs, and reclamation cost plans. In the event that the mining life is less than 5 (five) years, the Reclamation Plan is prepared according to the age of the mine. The reclamation plan must be submitted before starting exploitation / production operations. ${ }^{3}$

Based on the description, it can be concluded that efforts to restore the condition of the land so that it can function in accordance with its designation through reclamation, is not only the responsibility of the mining company, but also the responsibility of the Government, in this case the Minister, Governor and Regent / Mayor, because they are the ones conducting the assessment and approval of the Reclamation Plan, as well as supervising the implementation of reclamation by the mining companies. The reclamation costs needed to reverse the condition of the land must be borne by the Mining Company. Reclamation costs, as part of environmental management costs incurred during the production stage, are part of production costs, which is one of the factors that reduce business sales (revenue derived from company mining) to obtain gross profit (loss). ${ }^{4}$

In order to guarantee the compliance of mining companies to carry out reclamation in accordance with the Reclamation Plan, mining companies are required to provide a Reclamation Guarantee, the amount of which is in accordance with the Reclamation Cost Plan which has been approved by the Minister, Governor, and Regent / Mayor according to their respective authority. The stipulation of provisions regarding the obligation to provide reclamation guarantees can also give confidence to the community and related agencies in the ability of mining companies to implement environmental management plans, particularly in carrying out the reclamation of exmining land. ${ }^{5}$

In the provisions as stated in Article 24 paragraph (1) Minister of Energy and Mineral Resources Regulation Number 18 of 2008 stipulates that the reclamation guarantee must be placed by the company before the company it carries out exploitation / production operations. This regulation does not regulate reclamation guarantees in exploration activities. It is necessary to conduct a technical research, whether the exploration activity stage will not cause environmental damage so that the Government does not regulate the reclamation guarantee at this stage. Several things that need attention in connection with the provision of reclamation guarantees are as follows: ${ }^{6}$

a. Reclamation Cost Component

The Reclamation Cost Plan is prepared for each year for a period of 5 (five) years, the calculations include direct costs and indirect costs and are made in Rupiah or United States Dollar. Direct costs include costs for

\footnotetext{
${ }^{1}$ Ibid. Page 40

${ }^{2}$ Hartman. 1998. Sumber Daya Alam , Pemanfaatannya Demi Kesejahteraan Manusia Seutuhnya. Solo: Panepen Mukti. Page 40.

${ }^{3}$ Ibid. Page 45

${ }^{4}$ Ibid. Page 48

${ }^{5}$ Loc. Cit.

${ }^{6}$ Suwandhi. Op. Cit. Page. 20.
} 
land use, revegetation, prevention and control of acid mine drainage, and civil works. Meanwhile, indirect costs include costs of mobilization and demobilization, planning of reclamation activities, administration and benefits of third parties as reclamation contractors, and supervision.

b. Forms of Reclamation Guarantee Reclamation guarantees are given in several forms, namely: a) Time deposits, placed at Government banks in Indonesia on behalf of the Minister, Governor or Regent / Mayor qq. The company concerned, with a guarantee period in accordance with the reclamation schedule. b) Bank guarantees, which are issued by Government banks in Indonesia or branches of foreign banks in Indonesia or government-owned guarantee institutions, with a guarantee period in accordance with the reclamation schedule.

c. Insurance is issued by a Government bank in Indonesia or a branch of a foreign bank in Indonesia or a government-owned guarantee institution, with a guarantee period according to the reclamation schedule; or

d. Accounting Reserve, can be placed if the company meets one of the following requirements:

(1) Is a public company listed on a stock exchange in Indonesia, or listed on a stock exchange outside Indonesia; or

(2) The company has a total paid-up capital of not less than US $\$ 25,000,000.00$ (twenty five million United States dollars) as stated in the financial statements that have been audited by a public accountant registered with the Ministry of Finance. ${ }^{1}$

Companies that place the Reclamation Guarantee in the form of Accounting Reserve, are required to submit an annual financial report that has been audited by a public accountant. The form of reclamation guarantee placed by a mining company is determined by the Minister, Governor or Regent / Mayor according to their respective authorities. Placement of Reclamation Collateral Placement of reclamation guarantees must be made before the company carries out exploitation / production operations, although this placement does not eliminate the Company's obligation to carry out reclamation. In terms of reclamation costs more than the specified Reclamation Guarantee, the Company is responsible for covering the shortage of costs. This also applies to the implementation of reclamation by a third party appointed by the Minister, Governor or Regent / Mayor, in the event that a Mining Company is deemed unsuccessful in carrying out reclamation.

In connection with the disbursement or release of reclamation guarantees. Requests to disburse reclamation guarantees in the form of deposits or release of reclamation guarantees in the form of Bank Guarantees, Insurance and Accounting Reserves, can be submitted in stages according to the reclamation implementation stage, by attaching the Reclamation implementation report. The request is submitted by the Company to the Minister, Governor or Regent / Mayor according to their respective authority, who will then conduct an assessment to determine the amount of the reclamation guarantee that is disbursed or released. For the purpose of this assessment, the Minister, Governor or Regent / Mayor can conduct a field survey to assess the success of the reclamation which must then be stated in the form of an official report. ${ }^{2}$

In this regard, previously, in the old regulation, the government could only provide administrative sanctions for violations in the implementation of reclamation and post mining. However, with the existence of the new Minerba Law, namely Law Number 3 of 2020, the reclamation and post-mining guarantees are considered to be more stringent and effective, namely by implementing the obligation to carry out reclamation and post mining with a $100 \%$ success rate for mining permit holders, where the regulation contains also special criminal sanctions in the form of imprisonment and fines for miners who do not carry out reclamation and post-mining activities.

Reclamation and post mining points in Law no. 3/2020 states that IUP and IUPK holders whose business permits are revoked or expired but do not carry out reclamation and post-mining activities or do not place reclamation and post-mining guarantee funds can be sentenced to a maximum of five years in prison and a maximum fine of Rp. 100 billion. In addition to criminal sanctions, IUP and IUPK holders can be subject to additional penalties in the form of payment of funds in the context of implementing the reclamation and / or post-mining obligations which are the obligations of the IUP and IUPK holders. ${ }^{3}$

In Law No. 4 of 2009, there are two types of sanctions listed in it, namely administrative sanctions and criminal sanctions. However, violations of reclamation and post-mining activities only contain administrative sanctions. Administrative sanctions are listed in Article 151 of Law Number 4 of 2009. Apart from Law Number 4 of 2009, Government Regulation Number 78 of 2010 also contains provisions for administrative sanctions. Administrative sanctions are imposed if violated one of the provisions in the statement that the Minister, governor, or regent / mayor in accordance with their authority has the right to impose administrative sanctions on holders of IUP, IPR or IUPK for violating the provisions referred to in Article 40 paragraph (3), Article 40 paragraph (5), Article 4 1, Article 43, Article 70, Article 71 paragraph (I), Article 74 paragraph (4), Article 74 paragraph (6), Article 81 paragraph (I), Article 93 paragraph (3), Article 95, Article 96, Article 97, Article 98,

\footnotetext{
${ }^{1}$ Ibid. Page 22

${ }^{2}$ Rasyidi, Anwar. 2016. Kontekstualitas Industri Berbasis Sosial Kemasyarakatan. Yogyakarta: Aswaja. Page 25.

${ }^{3}$ Ibid. Page 27.
} 
Article 99, Article 100, Article 102, Article 103, Article 105 paragraph (3), Article 105 paragraph (4), - Article 107, Article 108 paragraph (I), Article 1 10, Article 111 paragraph (I ), Article 112 paragraph (I), Article 114 paragraph (2), Article 115 paragraph (2), Article 125 paragraph (3), Article 126 paragraph (I), Article 128 paragraph (1), Article 129 paragraph (11), or Article 130 paragraph (2).

If you violate any of the provisions of the articles above, you will be subject to administrative sanctions. The administrative sanctions are in the form of a written warning, temporary suspension of activities, and / or revocation of IUP, IUPK, and IPR. Holders of IUP, IUPK, and IPR who are subject to IUP, IUPK, and IPR revocation sanctions do not eliminate their obligations to carry out reclamation and post-mining activities. These administrative sanctions are given by the minister, governor or regent / mayor in accordance with their authority.

The imposition of administrative sanctions for reclamation and post-mining activities is unable to provide a deterrent effect on mining companies that violate their obligations to carry out reclamation and post-mining activities, besides that the possibility of being violated is very large. The provisions on the types of administrative sanctions are only given to the company, while those who run the company should also be subject to criminal sanctions, because in addition to being compelling and must be obeyed, there is a further process that must be followed up by law enforcement officials if it is indicated that it fulfills the elements of negligence and violations of the implementation of reclamation and post-mining ${ }^{1}$.

The effect of imposing criminal sanctions on mining entrepreneurs apart from giving a deterrent effect, also keeps away from the possibility of repeating violations in terms of not carrying out reclamation and post-mining activities. The granting of criminal sanctions is a form of seriousness from the government to make efforts to save the environment as a result of coal mining activities. The broad role of government is also balanced with the roles and functions of all existing stakeholders.

Apart from the government and mining companies, non-governmental organizations (NGOs), universities / research institutions and the community also have roles that complement one another. In this case, that reclamation and post-mining are responsibilities arising from the law, because Law Number 3 of 2020 concerning Minerals and Coal requires that reclamation and post-mining be carried out for IUP and IUPK holders. Authority granted by law this is given to the Government in the form of making regional regulations, granting permits to implement reclamation, developing and empowering local communities in mining businesses with due regard to environmental sustainability, guidance and supervision. ${ }^{2}$

Such broad government authority needs synergy between mining companies, communities, NGOs and universities / research institutions. $b$. The policy that can be taken by the government is to make local regulations in accordance with the conditions in South Sumatra. The Regional Regulation contains: first, post-mining land management that is environmentally based and sustainable. second, strengthening the synergy team in the form of a monitoring team for all stakeholders. Third, the community can participate in determining post-mining land management.

\section{E. Closing Notes}

The passing of Law on Minerba number 3 of 2020 has given a new color to mineral and coal mining in Indonesia. However, the reclamation that occurs in the regions is not like the news that has been circulating in newspapers and on social media. Conditions in the reclamation area are not running as they should. The companies only want to take advantage without having to think about their responsibilities for reclamation, especially under the mine. When viewed from above, there is a lot of underneath from increasing over time.

It is hoped that the regulation that was passed recently on mineral and coal can be fully implemented so that mining actors are deterred and responsible for carrying out reclamation. Of course, this is not free from cooperation between parties and there is no practice of bribery so that the law cannot be bought by money. Although basically everyone needs money to meet their needs and their families.

When compared with the old and new Minerba Law, the old Law can use a third party to reclaim the guarantee fund. So that the reclamation can still run. However, the new mineral and coal is added with criminal penalties for companies or mining actors who do not want to reclaim, so that the deterrent effect that is raised is greater than the old mineral and coal law. Because most people are more deterred when their freedom is lost.

For this reason, reclamation activities should be carried out and at the same time monitoring that is consistently enforced in the activity concerned. Supervision is needed as part of law enforcement, which includes the reclamation process and when untruth is found in reclamation activities, and immediate action should be taken to correct it in accordance with the prevailing laws and regulations.

Each related agency cooperates with each other and has the same mission to enforce the law and there is no practice of bribery, so that companies that do not carry out reclamation in accordance with the law will be dealt with strictly. The implementation of the law according to the law without any personal interest will bring

\footnotetext{
${ }^{1}$ Said, Salim. 2018. Mengelola Minerba Berwawasan Lingkungan Menuju Kesejahteraan Rakyat. Bandung: Lappera. Page 18.

Ibid. Page 20
} 
prosperity to the people.

\section{BIBLIOGRAPHY}

Abdulkadir, Zuwaini. 2017. Satuan Pemerintahan, Menuju Ketertiban Administrasi. Solo: Modernitas.

Adhan, Ade. 2020. Kebijakan Hukum Pidana Terhadap Tindak Pidana di Bidang Pertambangan Mineral dan Batubara dalam Undang-Undang Nomor 3 Tahun 2020 tentang Pertambangan Mineral dan Batubara, Tesis.Program Magister Ilmu Hukum Fakultas Hukum Universitas Diponegoro. Semarang.

Adjie, Habib. 2014. Status Badan Hukum, Prinsip-Prinsip dan Tanggung jawab Sosial Perseroan Terbatas. Bandung: CV. Mandar Maju.

Amintohari. 2017. Corporate Social Responsibility Membangun Masyarqakat Sejahtera. Bandung: Genta Publishing.

Anthony I. Ogus, 2004. Regulations Legal Form and Economic Theory. Portland, Oregon: Hart.

Asshiddiqie, Jimly 2009. Green Constitution: Nuansa Hijau UU Dasar Negara Republik Indonesia Tahun 1945. Jakarta: Rajawali Pers.

Atmadja, Muktar Kusuma. 2005. Konsep-konsep Hukum dalam Pembangunan, Ed. H.R. Otje Salman dan Edy Damain. Bandung: Alumni.

Atmosudirdjo, Prajudi. 1988. Hukum Tata Pemerintahan. Bandung: Alumni.

Azheri, Busyra. 2016. Corporate Social Responsibility,. Jakarta: PT. Rajawali Pers.

Berge, 2001. The Principle of Proportionality in Dutch Administrative Law dikutip dari Dr. GH. Addink, General Principles of Good Governance under General Administrative law (GALA), Utrecht University.

Brojonegoro, Sumali. 2017. Sumber Alam Primadona Devisa. Bandung: Irahana.

Budi, Hendrik. 2017. Corporate Social Responbilty. Jakarta: Sinar Grafika

Bukhori, Imam 2016. Tanggungjawab Sosial Perusahaan Berbasis Penanaman Modal Asing. Jakarta: Genta.

Chand, Hari. 1994, Modern Jurisprudence, International Law Book Services, Kuala Lumpur.

Departemen Pendidikan Nasional. 2016. Kamus Besar Bahasa Indonesia Pusat Bahasa. Jakarta: Gramedia Pustaka Utama.

Departemen Pertambangan dan Energi. 2019. Peretambangan Dalam Angka. Jakarta: Departemen ESDM.

Dewi, Kumala, 2017. Aspek Pengawasan dalam Pengelolaan Adminisgtrasi Pemerintahan Daerah. Semarang: Kaliwungu.

G.H. Addink, 2009. Public Environmental Law in the Nederlands, in: Comparative Environmental Law in Europa: An Introduction to Public Environmental Law in EU Member State, in: Penataran Environmental Law and Sustainable Development: Literature, Fakultas Hukum Unair, Surabaya

Hartman. 1998. Sumber Daya Alam , Pemanfaatannya Demi Kesejahteraan Manusia Seutuhnya. Solo: Panepen Mukti.

Hartman. 1998. Sumber Daya Alam , Pemanfaatannya Demi Kesejahteraan Manusia Seutuhnya. Solo: Panepen Mukti.

Haryati, Tri. 2011. Perizinan Pertambangan di Era Reformasi Pemerintahan Daerah Studi tentang Perizinan Pertambangan Timah di Pulau Bangka. (Ringkasan Disertasi, Program Pascasarjana Studi Doktor Ilmu Hukum, Fakultas Hukum Universitas Indonesia, 19 November 2011.

Khadduri, Majid. 1999. Teologi Keadilan Perspektif Islam. Surabaya: Risalah Gusti.

Khusairi. 2018. Urusan Pokok dan Urusan Konkuren dalam Pengelolaan Administrasi Pemerintahan Daeah. Bandung: Tiara.

Kifti, Mariatul. 2018. Sinkronisasi Pengaturan Mengenai Industri Peretambangan. Bandung: Publishers.

Kompas, 4 Mei 2017, Lingkungan Hidup Indonesia, Editorial.

Nachrowi, Yuwono. 2014. Orientasi Peretambangan Untuk Kesejahteraan Rakyat di Balik Kekuasaan Pengusaha. Bandung: Mizan.

Nango, Umbu. 2018. Kriminal dan Kriminalisasi Pada Pidana Pertambangan. Tesis Program Magister Ilmu Hukum Universitas Marwadewa Denpasar.

Nasution, Helza Nova Lita, Fatmie Utarie. 2013. "Perlindungan Hukum Masyarakat Adat di Wilayah Pertambangan Lex Jurnalica” Volume 10 Nomor 3, Desember 2017.

Nazmi, Istidzlam. 2017. Adnministrasi Pemerintahan Profesional. Panduan Para Birokrat Daerah. Semarang: Kali Wungu.

Nugraha, Safri. dkk. 2009. Hukum Administrasi Negara. Depok: Penerbit Fakultas Hukum Universitas Indonesia.

Nur, Amran. 2015. Laporan Kerusakan Lingkungan Akibat Penambangan Batubara. Medan: Universitas Sumatera Utara.

Rangkuti, Siti Sundari. 1989. Hukum Lingkungan di Indonesia. Surabaya: Airlangga University Press. Rasyidi, Anwar. 2016. Kontekstualitas Industri Berbasis Sosial Kemasyarakatan. Yogyakarta: Aswaja. Riant N. D.2007. Analisis Kebijakan. Jakarta : Elex Media Komputindo.

Ridha Saleh, M. 2016. Lingkungan Hidup: Untuk Kehidupan Tidak Untuk Pembangunan. Jakarta: WALHI. 
Rusian, Rosady.2009 “Permasalahan Corporate Social Responbilty di Indonesia”. Jakarta: Salemba Empat.

Said, Salim. 2018. Mengelola Minerba Berwawasan Lingkungan Menuju Kesejahteraan Rakyat. Bandung: Lappera.

Saleng, Abrar. 2004, Hukum Pertambangan, Yogyakarta : UII press.

Salim, 2015. Hukum Pertambangan Di Indonesia, Jakarta : Rajawali Pers.

Salim, Emil. 2009, Lingkungan Hidup dan Pembangunan. Jakarta: Mutiara Sumber Widya.

Sukadarrumidi, 1999, Bahan Galian Industri, Yogyakarta: Gadjah Mada University Press.

Sukadarrumidi, 1999, Bahan Galian Industri, Yogyakarta: Gadjah Mada University Press.

Sukadi, Khoirul. 2009. Sumber Daya Mineral Untuk Pembangunan Sumber Daya Manusia Bangsa. Surabaya: Talenta.

Sukadi, Khoirul. 2009. Sumber Daya Mineral Untuk Pembangunan Sumber Daya Manusia Bangsa. Surabaya: Talenta.

Sukadi, Khoirul. 2019. Sumber Daya Mineral Untuk Pembangunan Sumber Daya Manusia Bangsa. Surabaya: Talenta.

Sukamdhani, Norkhayyin. 2017. Jabaran Prinsip Desentralisasi, Dekonsentrasi dan Medebewind. Bandung: Tiara.

Wahidin, Samsul. 2015. Pokok-pokok Perlindungan dan Pengelolaan Lingkungan Hidup. Yogyakarta: Pustaka Pelajar.

\section{Media Online}

https://fokus.tempo.co/read/1341880/kontroversi-uu-minerba-yang-bakal-diujimaterikan-ke-mk/full\&view=ok https://idcloudhost.com/mengenal-apa-itu-csr-manfaat-dan-jenisnya/

https://industri.kontan.co.id/news/ini-poin-penting-dalam-uu-minerba-yang-baru-disahkan

https://industri.kontan.co.id/news/ini-poin-poin-penting-dalam-uu-minerba-yang-baru-disahkan

https://industri.kontan.co.id/news/ini-poin-poin-penting-dalam-uu-minerba-yang-baru-

disahkanhttps://irto.id/greenpeace-uu-minerba-cederai-desentralisasi-Daerah-era-reformasi-fMe6.

https://media.neliti.com/media/publications/18046-ID-perlindungan-hukum-masyarakat-adat-di-wilayah-

pertambangan.pdfhttp:/www.apbi-icma.org/news/3152/undang-undang-no-3-tahun-2020-tentang-

perubahan-uu-no-4-tahun-2009https://www.mongabay.co.id/2020/06/19/hilangnya-partisipasi-masyarakatpada-perubahan-uu-minerba/

https://media.neliti.com/media/publications/48852-ID-kajian-indikator-sustainable-development-goals.pdf. 